\title{
On the occurrence of Coronaster briareus (Echinodermata, Forcipulatida, Asteriidae) in the Mediterranean Sea
}

\author{
Julian Evans ${ }^{1}$ (D) - Leyla Knittweis ${ }^{1} \cdot$ Ricardo Aguilar $^{2} \cdot$ Helena Alvarez $^{2}$. \\ Joseph A. Borg ${ }^{1} \cdot$ Silvia Garcia ${ }^{2}$ Patrick J. Schembri ${ }^{1}$
}

Received: 14 October 2016 /Revised: 21 November 2016 / Accepted: 23 November 2016 /Published online: 10 December 2016

(C) Senckenberg Gesellschaft für Naturforschung and Springer-Verlag Berlin Heidelberg 2016

\begin{abstract}
The sea star Coronaster briareus (Verrill Am J Sci (Ser III), 1882) is reported for the first time from the Mediterranean Sea. A total of 26 individuals were sighted in Maltese waters during ROV surveys made in July 2015 and June-July 2016. The identity of the species was confirmed through morphological examination of a specimen collected in June 2016. This identification is discussed in the light of inconsistencies in the published descriptions of species of Coronaster recorded from the Atlantic, and of individuals belonging to this genus recorded from the eastern Atlantic and whose coloration does not match that of $C$. briareus or C. volsellatus (the only species of Coronaster hitherto known from the Atlantic). The presence of numerous individuals of C. briareus in Maltese waters, recorded on two occasions a year apart over a relatively large area, indicates that there is an established population. This represents a considerable expansion of the distribution range of this species, which is mostly known from the western Atlantic. Possible reasons for its presence in Maltese waters are discussed, but the dynamics of the occurrence of $C$. briareus in the central Mediterranean remain unknown.
\end{abstract}

Keywords Deep sea $\cdot$ Malta $\cdot$ Newcomer $\cdot$ Range expansion $\cdot$ ROV $\cdot$ Sicily channel

Communicated by S. Stöhr

Julian Evans

julian.evans@um.edu.mt

1 Department of Biology, Faculty of Science, University of Malta, Msida MSD2080, Malta

2 Fundacion Oceana, Gran Via 59, 28013 Madrid, Spain

\section{Introduction}

The Mediterranean Sea is one of the most intensively investigated regions of the world in terms of marine species diversity, but deep-sea areas are relatively poorly known compared to their shallow-water counterparts (Coll et al. 2010). In particular, most studies on the species composition and diversity of the deep-sea megabenthic fauna of the Mediterranean have concerned fishes or crustaceans (Danovaro et al. 2010 and references therein), and knowledge of other faunal groups such as echinoderms remains scant (Mecho et al. 2014). Furthermore, most studies have traditionally focused on areas with soft sedimentary bottoms that could be sampled using standard sampling gears such as trawls, dredges and grabs, whereas until recently areas characterised by hard rocky bottoms have generally escaped the attention of biologists due to difficulties in adequately sampling these substrata (Taviani et al. 2016).

Recent deep-water exploration is improving knowledge of the Mediterranean deep-sea echinoderm assemblages. On the one hand, several recent studies based on trawl surveys have analysed megabenthic fauna other than fish and crustaceans (Cartes et al. 2009; Mifsud et al. 2009; Ramirez-Llodra et al. 2010; Tecchio et al. 2011; Mecho et al. 2014). For example, recent studies by Mifsud et al. (2009) and Mecho et al. (2014) have led to the discovery of an ophiuroid and an echinoid new for the Mediterranean, the rediscovery of an endemic holothurian previously known from a single individual collected in 1914, and better knowledge on the spatial and bathymetric distribution of several other benthic echinoderms. At the same time, the advent of remotely operated vehicles (ROVs) has enabled the exploration of such geomorphological features as seamounts, canyons and escarpments. In the Mediterranean, ROV surveys have tended to focus on coldwater coral assemblages (Freiwald et al. 2009; Orejas et al. 
2009; Vertino et al. 2010; Angeletti et al. 2014; Fabri et al. 2014; Taviani et al. 2016), but these have also yielded new information on echinoderms, such as the discovery of extensive crinoid facies in Montecristo Island (Angeletti et al. 2010). Elsewhere, outside the Mediterranean, ROV surveys have also led to the rediscovery of echinoderm species (Gebruk et al. 2003) or observations on their behaviour (Hudson et al. 2004; Hughes et al. 2010) and associated assemblages (Fonseca et al. 2014).

The situation in the central Mediterranean mirrors that of the basin as a whole: knowledge concerning deep-sea species is limited due to lack of studies, and, although recent studies have started to address this gap, these have mostly focused on areas with soft bottoms amenable to trawl sampling (Terribile et al. 2016). Similarly, only a few exploratory ROV surveys have been undertaken in the region, which were mostly aimed at searching for the possible presence of deep-water corals (Freiwald et al. 2009; Deidun et al. 2015). Data on echinoderms in the region reflect this state of affairs. For example, in the case of the Asteroidea, a total of 19 deep-water (maximum depth $>200 \mathrm{~m}$ ) species are included in the most recent inventory of Mediterranean echinoderms (Coll et al. 2010). Of these, 13 species are known from the central Mediterranean, which is lower than the number of species recorded from the western Mediterranean (19 species), the Adriatic Sea (16 species) and the Aegean Sea (15 species). This is probably due to limited sampling effort in the central Mediterranean region, which is expected to have a higher species richness than the Adriatic or Aegean Seas since it abuts directly on the western Mediterranean (Koukouras et al. 2007).

Within this context, we present here a new addition to the deep-sea asteroid fauna of the Mediterranean, C. briareus (Verrill 1882), which was originally recorded from Maltese waters on the basis of remotely recorded images and video footage collected in July 2015. Photo-identification of the species was not conclusive, but the identity of the Maltese specimens was confirmed through morphological examination of an individual collected in June 2016. The present record of $C$. briareus represents a considerable expansion of the known distribution range of this species. The identification of the species and possible mechanisms accounting for its occurrence in the central Mediterranean are discussed.

\section{Material and methods}

Benthic surveys using a ROV (Saab Seaeye Falcon DR) were undertaken by the research catamaran Oceana Ranger during June-July 2015 and June-July 2016 within the 25-nauticalmile Fisheries Management Zone surrounding the Maltese Islands. The ROV was equipped with high-definition photo and video cameras and a tracking system that recorded its position and depth, hence providing detailed information on the surveyed tracks along the seabed. A total of 206 ROV dives were made during the two sets of surveys.

A small number of individuals of a multi-armed asteroid that did not match any of the sea stars known from the Mediterranean were observed during the first set of surveys (July 2015). Characteristics visible in the high-resolution images, including the number of rays (10-11), the abactinal skeleton consisting of a reticulated network of quadrate meshes, and the presence of five longiseries of solitary spines each with a conspicuous wreath of pedicellariae, indicated they belonged to the genus Coronaster.

We attempted to identify the species based on the images, and analysed photos of Coronaster sp. taken in the eastern Atlantic [Gorringe Bank, Gulf of Cadiz, El Hierro (Canary Islands), and Triton Seamount (north of Canary Islands)] independently of the present study for comparison with the Maltese specimens. However, photo-identification proved difficult, partly due to inconsistencies in the published descriptions of Coronaster species, which are mostly based on preserved specimens. Individuals of the same species of Coronaster recorded from Maltese waters in 2015 were sighted again during the 2016 surveys, and this time it was possible to collect one of the specimens using the ROV's arm, allowing for detailed morphological examination. Given the queries that arose when attempting photo-identification, the anatomical features observed were compared to those of all currently valid species of Coronaster included in the WoRMS database (Mah and Hansson 2016) in order to ensure accurate identification. All the ROV video footage collected during the two sets of surveys was subsequently analysed to record all occurrences of the Coronaster species, together with information on the bottom type where each specimen was observed.

\section{Results}

\section{Species description}

Twenty-six individuals of a species of Coronaster were recorded from Maltese waters, 12 in July 2015 and 14 between June and July 2016 (Fig. 1; see also Table 1), which we identified as $C$. briareus based on morphological examination of an individual collected in June 2016 (see below). The individuals had a relatively small disc and 10 or 11 slender rays [radius from disc centre to arm tip $(R) /$ radius from disc centre to interradial edge of disc $(r) \approx 10-20]$, and were estimated to have a total diameter of between 18 and $25 \mathrm{~cm}$. The skeletal armature on the arms consisted of five radial rows of plates (one carinal, plus one superomarginal and one inferomarginal series on either side of the ray) connected by transverse plates, giving a reticulated network of square meshes on the aboral surface of the rays. A slender spine encircled by a dense wreath of pedicellariae originated at each skeletal node, 

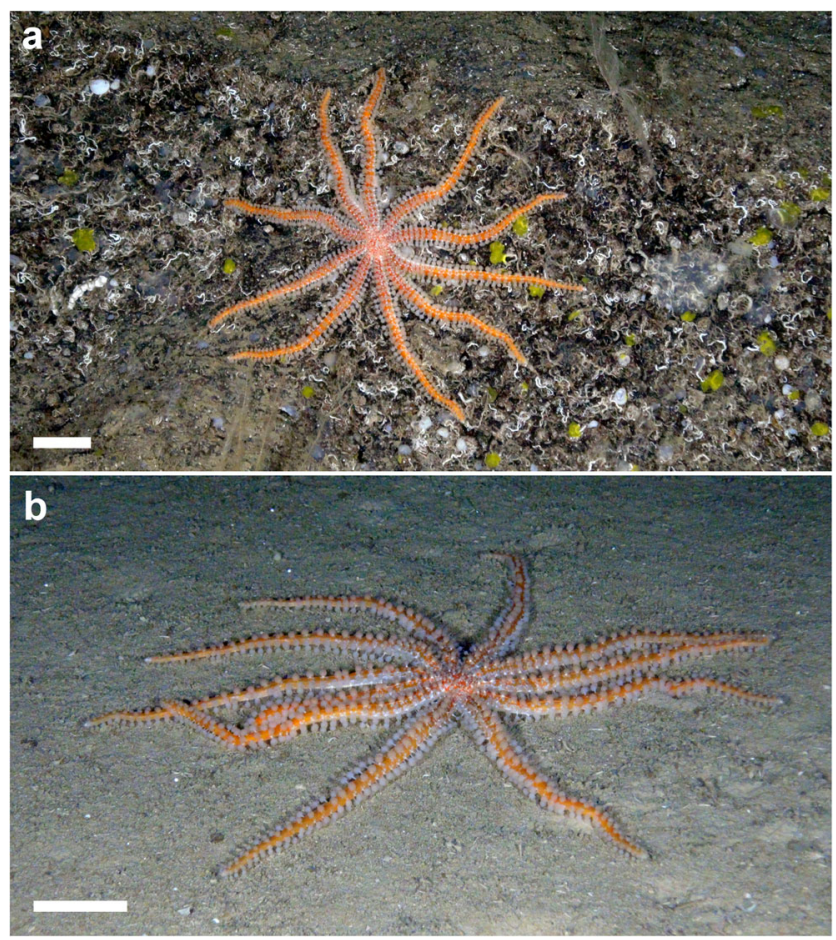

Fig. 1 In situ images of individuals of Coronaster briareus recorded from Maltese waters in July 2015: a 10-rayed individual on a hard bottom at $285 \mathrm{~m}$ depth; b 11-rayed individual on a soft bottom at $334 \mathrm{~m}$ depth. Scale bars $25 \mathrm{~mm}$. (Photos: OCEANA @ LIFE BaHAR for N2K)

resulting in five radial rows of spines on the arms. Clusters of papulae were present within the rectangular meshes. The disc was also adorned with wreathed spines and papular clusters. The individuals had an orange-red coloration on the dorsal surface, except at the base of the spines and in the papular areas, which were white. The marginal areas were also white.

Details on the morphological features of the specimen collected in June 2016 are illustrated in Fig. 2. The specimen measures $125 \mathrm{~mm}$ in $R$ and $8 \mathrm{~mm}$ in $r$. The skeletal structure of the arms is as described above (Fig. 2a-d), except in one of the longer arms where the arrangement of plates in the proximal part of the arm is less regular, and small spines are present on the connecting plates between the carinal and superomarginal series (Fig. 2c). The papulae occur in clusters, and tend to be situated at the corners of the square meshes.

Three types of pedicellariae are present (Fig. 2e-g). Small crossed pedicellariae form the wreath around the spines. These pedicellariae have enlarged terminal teeth and a series of lateral teeth, generally occurring in two rows of six teeth, although some crossed pedicellariae with only one row of lateral teeth were also observed. Small straight pedicellariae having the jaws crossed at the tips were found in the papular areas, along the ambulacaral groove and surrounding the oral plates. Large felipedal (unguiculate) pedicellariae, having a broad shape with the proximal third slightly narrowed and five long claws at the tip, were only observed in between the rays where these connect with the disc.

The adambulacral plates are diplacanthid, with the two spines clearly arranged as a double series (Fig. 2h-i). The inner spine facing the ambulacral furrow is about half the length of the outer one. The tube feet are biserial close to the disc, but become crowded and arranged in a zig-zag pattern in the wider portions of the arms, appearing almost quadriserial in some regions (Fig. 2h). The oral plates are elongate, with one long acicular oral spine and a shorter adjacent lateral spine, the latter projecting across the furrow; there are no felipedal pedicellariae around these plates (Fig. 2j).

As part of our initial attempt at photo-identification, we also examined ROV images of a total of 19 individuals of Coronaster sp. from the eastern Atlantic, including 11 specimens from Triton Seamount, 4 from off El Hierro, 3 from the Gulf of Cadiz and 1 from Gorringe Bank. These were originally tentatively identified as C. volsellatus (Sladen 1889) (Oceana 2014; Álvarez et al. 2016) and served as useful comparative material, being the records that are least distant from the Maltese Islands. The eastern Atlantic individuals had a skeletal structure with regular quadrate meshes with wreathed spines at the intersections as described for the Maltese specimens above, but differed in terms of coloration since their abactinal surface had a cream colour (Fig. 3).

\section{Distribution and habitats}

Of the 26 individuals of $C$. briareus observed in Maltese waters (Table 1; Fig. 4), all but 1 were recorded from an area known as the 'South Malta Coral Province' (Schembri et al. 2007; Taviani et al. 2010), the boundary of which is located some $35 \mathrm{~km}$ to the southwest of the island of Malta. These individuals were observed in 10 different ROV transects, over a 20-km-wide area characterised by a plateau at a depth of around $300 \mathrm{~m}$ with a steep escarpment along the southern side extending down to a depth of around $600 \mathrm{~m}$. Fifteen individuals were recorded on soft detritic bottoms consisting of unconsolidated fine sediment with small embedded stones, while another ten individuals were found associated with rocky bottoms. The remaining individual was observed in an entirely different region to the northwest of the Maltese Islands, approximately $75 \mathrm{~km}$ from the other sightings, and on a rocky bottom. The overall depth range of the recorded specimens was $240-562 \mathrm{~m}$.

\section{Discussion}

\section{Identification}

The genus Coronaster includes eight species currently recognised as valid (Mah and Hansson 2016). None of these 
Table 1 Records of Coronaster briareus from Maltese waters, with data on location, depth, morphology (ray count and major radius / minor radius $[R / r]$ ratio) and bottom-type

\begin{tabular}{|c|c|c|c|c|c|c|}
\hline Date & Latitude & Longitude & Depth (m) & No. of rays & $R / r$ & Bottom-type \\
\hline 01/07/2015 & $35.516233^{\circ} \mathrm{N}$ & $14.371350^{\circ} \mathrm{E}$ & 285 & 10 & 17.0 & Rocky \\
\hline 01/07/2015 & $35.516267^{\circ} \mathrm{N}$ & $14.371372^{\circ} \mathrm{E}$ & 283 & 10 & 15.6 & Rocky \\
\hline 01/07/2015 & $35.527417^{\circ} \mathrm{N}$ & $14.384000^{\circ} \mathrm{E}$ & 271 & 10 & 14.3 & Rocky \\
\hline 01/07/2015 & $35.543450^{\circ} \mathrm{N}$ & $14.243583^{\circ} \mathrm{E}$ & 340 & 11 & 20.4 & Detritic \\
\hline 01/07/2015 & $35.543783^{\circ} \mathrm{N}$ & $14.243917^{\circ} \mathrm{E}$ & 334 & 11 & 18.3 & Detritic \\
\hline 01/07/2015 & $35.544017^{\circ} \mathrm{N}$ & $14.244067^{\circ} \mathrm{E}$ & 325 & 10 & 14.7 & Detritic \\
\hline 01/07/2015 & $35.544467^{\circ} \mathrm{N}$ & $14.244235^{\circ} \mathrm{E}$ & 321 & 10 & 17.0 & Detritic \\
\hline 01/07/2015 & $35.545250^{\circ} \mathrm{N}$ & $14.244367^{\circ} \mathrm{E}$ & 321 & 11 & 13.0 & Detritic \\
\hline 01/07/2015 & $35.545317^{\circ} \mathrm{N}$ & $14.244483^{\circ} \mathrm{E}$ & 323 & 10 & 19.6 & Detritic \\
\hline 01/07/2015 & $35.545183^{\circ} \mathrm{N}$ & $14.244550^{\circ} \mathrm{E}$ & 323 & - & - & Detritic \\
\hline 01/07/2015 & $35.545200^{\circ} \mathrm{N}$ & $14.244833^{\circ} \mathrm{E}$ & 323 & 11 & 13.7 & Detritic \\
\hline $15 / 07 / 2015$ & $36.175183^{\circ} \mathrm{N}$ & $13.939017^{\circ} \mathrm{E}$ & 367 & - & - & Rocky \\
\hline $24 / 06 / 2016$ & $35.522983^{\circ} \mathrm{N}$ & $14.355033^{\circ} \mathrm{E}$ & 427 & 11 & 18.5 & Detritic \\
\hline $24 / 06 / 2016$ & $35.522267^{\circ} \mathrm{N}$ & $14.355783^{\circ} \mathrm{E}$ & 427 & - & - & Detritic \\
\hline $25 / 06 / 2016$ & $35.515733^{\circ} \mathrm{N}$ & $14.364817^{\circ} \mathrm{E}$ & 256 & 10 & 15.2 & Rocky \\
\hline $25 / 06 / 2016$ & $35.512683^{\circ} \mathrm{N}$ & $14.358650^{\circ} \mathrm{E}$ & 562 & 10 & 15.6 & Detritic \\
\hline $25 / 06 / 2016$ & $35.532217^{\circ} \mathrm{N}$ & $14.318533^{\circ} \mathrm{E}$ & 407 & 10 & 14.9 & Detritic \\
\hline $25 / 06 / 2016$ & $35.531083^{\circ} \mathrm{N}$ & $14.317983^{\circ} \mathrm{E}$ & 412 & 11 & 17.4 & Detritic \\
\hline $25 / 06 / 2016$ & $35.536200^{\circ} \mathrm{N}$ & $14.302783^{\circ} \mathrm{E}$ & 257 & 10 & 10.8 & Rocky \\
\hline $25 / 06 / 2016$ & $35.537167^{\circ} \mathrm{N}$ & $14.302183^{\circ} \mathrm{E}$ & 267 & 11 & 10.4 & Rocky \\
\hline 26/06/2016 & $35.538217^{\circ} \mathrm{N}$ & $14.225067^{\circ} \mathrm{E}$ & 400 & 10 & 19.1 & Detritic \\
\hline 26/06/2016 & $35.538050^{\circ} \mathrm{N}$ & $14.224950^{\circ} \mathrm{E}$ & 393 & - & - & Rocky \\
\hline 26/06/2016 & $35.537283^{\circ} \mathrm{N}$ & $14.224550^{\circ} \mathrm{E}$ & 390 & - & - & Detritic \\
\hline 21/07/2016 & $35.538917^{\circ} \mathrm{N}$ & $14.267783^{\circ} \mathrm{E}$ & 240 & 11 & 16.0 & Rocky \\
\hline $21 / 07 / 2016$ & $35.538000^{\circ} \mathrm{N}$ & $14.266983^{\circ} \mathrm{E}$ & 251 & 10 & 19.2 & Rocky \\
\hline 21/07/2016 & $35.536983^{\circ} \mathrm{N}$ & $14.174600^{\circ} \mathrm{E}$ & 458 & - & - & Rocky \\
\hline
\end{tabular}

are known from the Red Sea or Indian Ocean, while only two species, C. briareus and C. volsellatus, are known from the Atlantic (Clark and Downey 1992). The remaining six species occur only in the Pacific Ocean. Given the distributions of these species, it seemed likely that the Maltese specimens would belong to one of the two species known from the Atlantic, with $C$. volsellatus the most likely candidate given it has been recorded (as C. antonii Perrier 1894) from off Morocco (Perrier 1894) and the Bay of Biscay (Koehler 1895, 1896).

According to Clark and Downey (1992), the main feature distinguishing the two Atlantic species is the number of spines on the adambulacral plates (two in C. briareus; one in $C$. volsellatus), while there are also differences in the shape of the large felipedal pedicellariae (short, broad valves with long acute terminal teeth in C. briareus; long, narrow valves with a constriction in the middle, and short, blunt terminal teeth in $C$. volsellatus). Neither of these features was visible in the images taken by the ROV in July 2015 and, not knowing whether the species would be encountered again, we looked up descriptions of specimens from the Atlantic to try and find alternative distinguishing characters. Perrier (1894) suggested that C. parfaiti $[=$ briareus $]$ and $C$. antonii $[=$ volsellatus $]$ differ in terms of the number of arms, their $R / r$ ratio, and in the position of the wreath of pedicellariae on the spines, but none of these are reliable characters: arm count is variable and there is overlap between the two species, the $R / r$ ratio depends on maturity (and according to Clark and Downey (1992) Perrier's specimens were immature), and the wreath of pedicellariae is borne on a retractile sheath (Fisher 1917; Clark and Downey 1992). Therefore, we were unable to identify the species based solely on the images taken by the ROV.

During this exercise, some anomalies in the published descriptions were noted. For reference, a timeline summarising the main contributions of different authors is provided in Table 2. The key issues identified were:

- $\quad$ Perrier (1885) originally described C. parfaiti as having a single adambulacral spine, but later (Perrier 1894) reported the same specimen to have two such spines; Clark and 


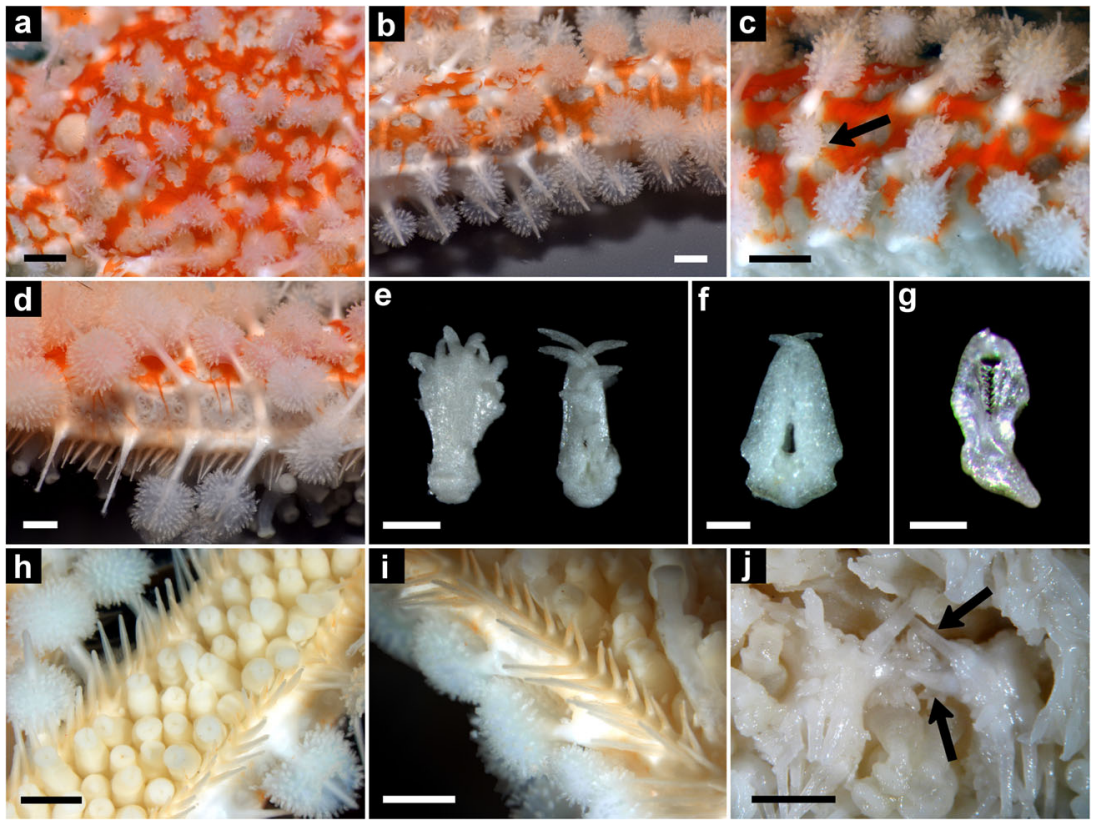

Fig. 2 Aspects of the morphology of a specimen of Coronaster briareus collected from Maltese waters in June 2016: a close-up of disc showing wreathed spines and papulae; $\mathbf{b}$ dorsal view of ray showing the skeletal arrangement, wreathed spines and papulae; $\mathbf{c}$ dorsal view of ray showing additional spines (arrow) on cross-plates connecting carinal and superomarginal plates; d lateral view of ray showing marginal area; photomicrographs: of e large felipedal, f small straight and $\mathbf{g}$ crossed pedicellariae; $\mathbf{h}$ ventral view of ray showing tube feet and adambulacral spines; $\mathbf{i}$ close-up of series of adambulacral spines showing diplacanthid arrangement; $\mathbf{j}$ oral plates showing oral and lateral spines (arrows). Scale bars (a-d, h-j) $2 \mathrm{~mm}$; (e) $0.5 \mathrm{~mm}$; (f, g) $0.1 \mathrm{~mm}$. (Photos: a, b, d: OCEANA / Carlos Minguell (C) LIFE BaHAR for N2K; Photos $\mathbf{c}, \mathbf{e}-\mathbf{j}$ : Julian Evans (C) LIFE BaHAR for N2K)

Downey (1992) considered Perrier's type specimen to be an immature $C$. briareus, which has two adambulacral spines.

- Perrier (1894) described C. antonii as having two adambulacral spines, and this remained a valid species until Clark and Downey (1992) commented that Perrier's type specimen is "not specifically distinct from C. volsellatus", even though $C$. volsellatus has only a single adambulacral spine. The implication seems to be that Perrier's specimen also only had a single spine. Another three specimens of $C$. antonii, each with two adambulacral spines, were reported from the Bay of Biscay by Koehler (1895, 1896). However, Clark and Downey list Morocco (the type locality) as the only locality for C. volsellatus in the Atlantic, and it is not clear whether they examined other specimens from the Atlantic besides Perrier's type specimen of $C$. antonii.

- $\quad$ Perrier $(1885,1894)$ described $C$. parfaiti $[=$ briareus $]$ as having an orange and white coloration, while Clark and Downey (1992) state that $C$. volsellatus has a bright salmon red colour. Therefore, the individuals of Coronaster sp. we recorded from the eastern Atlantic, which have a cream coloration, do not match either description.

The collection of a specimen in June 2016 allowed identification of the species found in the central Mediterranean. Given the above inconsistencies, we opted to take all eight species of Coronaster into consideration. Of these, $C$. volsellatus is the only one with monacanthid adambulacral plates, and the shape of the large felipedal pedicellariae also differs from those of the Maltese specimens (Fisher 1919; Clark and Downey 1992). C. eclipes Fisher, 1925, C. marchenus Ziesenhenne, 1942, and C. pauciporis Jangoux, 1984 were also excluded since they lack large felipedal pedicellariae altogether, while $C$. reticulatus (Clark, 1916) only possesses six rays (Ziesenhenne 1942; McKnight 2006). In the case of C. sakuranus (Döderlein, 1902) the skeletal plates connecting the carinal and superomarginal plates are irregularly arranged so the skeleton does not form regular quadrate meshes but a series of reticulated polygons (Hiyashi 1943; Chao 2000). The remaining species, C. halicepus Fisher, 1917, has a similar skeletal arrangement to C. briareus but differs in the spinulation of the oral plates, having two subequal oral spines and a suboral spine arising at the centre of the plate (Fisher 1919).

Therefore, the Maltese specimens were confirmed to be C. briareus, and the individual examined matched the original description of this species by Verrill (1882) as well as more recent ones (e.g. Downey 1973; Clark and Downey 1992), except in the position of the large felipedal pedicellariae. However, this does not appear to be a consistent feature across individuals. According to Verrill (1882), these pedicellariae occur scattered between the spines. Downey (1973) stated they are found on the disc, within the ambulacral groove, and elsewhere on the surface, 

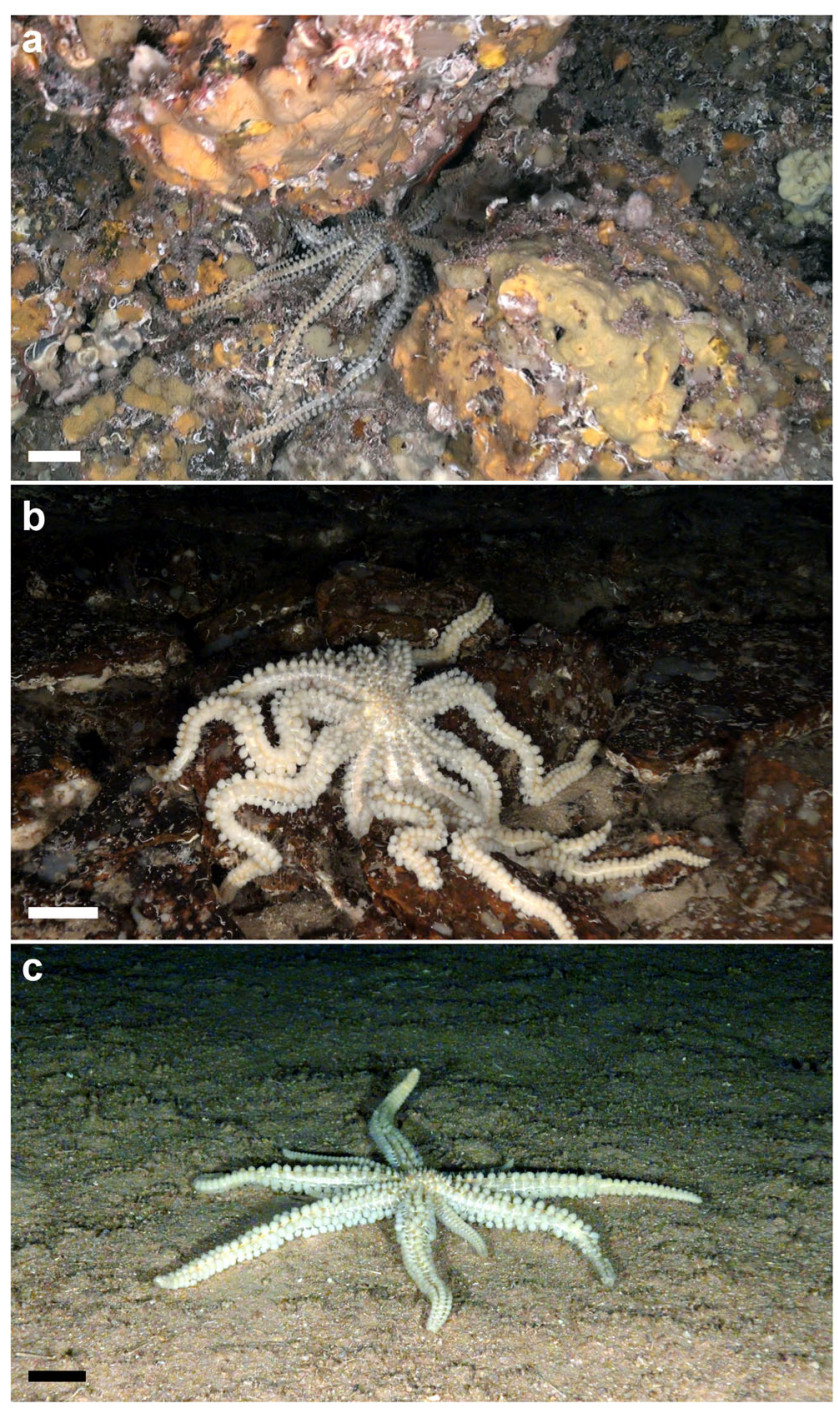

Fig. 3 In situ images of individuals of Coronaster sp. from the eastern Atlantic, recorded from: a Gorringe Bank at a depth of $196 \mathrm{~m}$ in August 2011, b Gulf of Cadiz at a depth of 329 m in July 2011, and c Triton Seamount at a depth of $264 \mathrm{~m}$ in September 2014. Scale bars $25 \mathrm{~mm}$. (Photos $\odot$ OCEANA)

while Clark and Downey (1992) observed them mostly on the actinal surface of the disc around the mouth.

On the other hand, the identity of the Coronaster sp. recorded from Triton Seamount, El Hierro, Gorringe Bank and the Gulf of Cadiz remains unresolved. The fact that their coloration is different to that reported for both $C$. volsellatus and $C$. briareus suggests there may be another species of Coronaster in the eastern Atlantic, or at least a different colour morph of one of the known species. However, this cannot be ascertained in the absence of actual specimens.

\section{Distribution and habitats}

The presence of 25 individuals in an area extending over $20 \mathrm{~km}$ plus a further individual observed $75 \mathrm{~km}$ away, together with the fact that individuals were observed in both July 2015 and June-July 2016, indicates that a population of $C$. briareus is established in Maltese waters. The recorded depths (240$562 \mathrm{~m}$ ) are within those reported for the Atlantic, which range from 50 to $700 \mathrm{~m}$ (Clark and Downey 1992). Similarly, C. briareus is known to occur on both hard (Perrier 1894; Pawson et al. 2009) and soft (Verrill 1884; Messing et al. 2006) bottoms, so the observations made in Maltese waters are in agreement with the known habitats of this species.

C. briareus is mostly known from the western Atlantic, where it extends from New Jersey to Venezuela and possibly South Brazil (Clark and Downey 1992). In the eastern Atlantic, it was recorded from the Cape Verde Islands (Perrier 1894; Clark and Downey 1992), as well as from the Great Meteor Seamount and Irving Seamount (Muséum National d'Histoire Naturelle, Paris, specimen codes: MNHN-IE-2013-6472 and MNHN-IE-2013-6550). The distribution data in the WoRMS database (Mah and Hansson 2016) also lists Madeira and the Canary Islands, citing Clark and Downey (1992), but this appears to be an error. In their chapter on distributions, Clark and Downey (1992) do include C. briareus in the combined category "Madeira, Cape Verde and Canary Islands" (p. 501), but only because this species was recorded from the Cape Verde Islands, as clearly indicated in the detailed species description (p. 460). An orange-red specimen reported as Coronaster sp. was also recorded from the Alboran Sea (Hebbeln et al. 2009), but the identity of the species was not determined and may have been $C$. volsellatus. The closest confirmed record of $C$. briareus to the Mediterranean Sea is therefore over $2000 \mathrm{~km}$ from the Strait of Gibraltar, and almost $4000 \mathrm{~km}$ distant from the Maltese Islands. We can only speculate as to the origin of the population recorded from Maltese waters. Three possibilities arise: (1) C. briareus was recently introduced into the Mediterranean through anthropogenic activities, making it another addition to the non-indigenous fauna of this sea; (2) C. briareus has undergone a recent autochthonous range expansion, presumably through larval dispersal, allowing it to colonise the central Mediterranean; and (3) C. briareus is a native Mediterranean species where it occurs only in deeper waters, but has not been detected up until now.

A human-mediated introduction may have occurred via shipping, which is an important vector for introduction of alien species into the Mediterranean, including the Maltese Islands (Galil et al. 2014; Evans et al. 2015). Translocation of adults is highly unlikely in this case, but transportation of larvae in ballast tanks is a possibility. However, most of the Atlantic records of $C$. briareus are from offshore waters deeper than $100 \mathrm{~m}$, reducing the probability that larvae of this species are taken up with ballast water. Moreover, shipping would seem to be a more plausible mode of introduction if the Maltese specimens were found close to a port, rather than $35 \mathrm{~km}$ from the coast at depths of over $200 \mathrm{~m}$. There appears 
Fig. 4 a The Maltese Islands showing the distribution of Coronaster briareus individuals recorded through remotely operated vehicle surveys made in 2015 and 2016 (blue circles) and sites that were surveyed but where no $C$. briareus were recorded (black dots); the 25-nautical-mile Fisheries Management Zone (oval) around Malta is also shown. b Close-up of escarpment forming part of the 'South Malta Coral Province', showing multibeam bathymetry and position of survey sites where C. briareus was present (blue circles; number indicates the number of specimens recorded at the site) or absent (black circles). Only 1 of the 26 individuals of C. briareus was recorded outside of this zone. (Multibeam bathymetry courtesy of ISMAR-CNR, Bologna; modified from Angeletti and Taviani 2011)
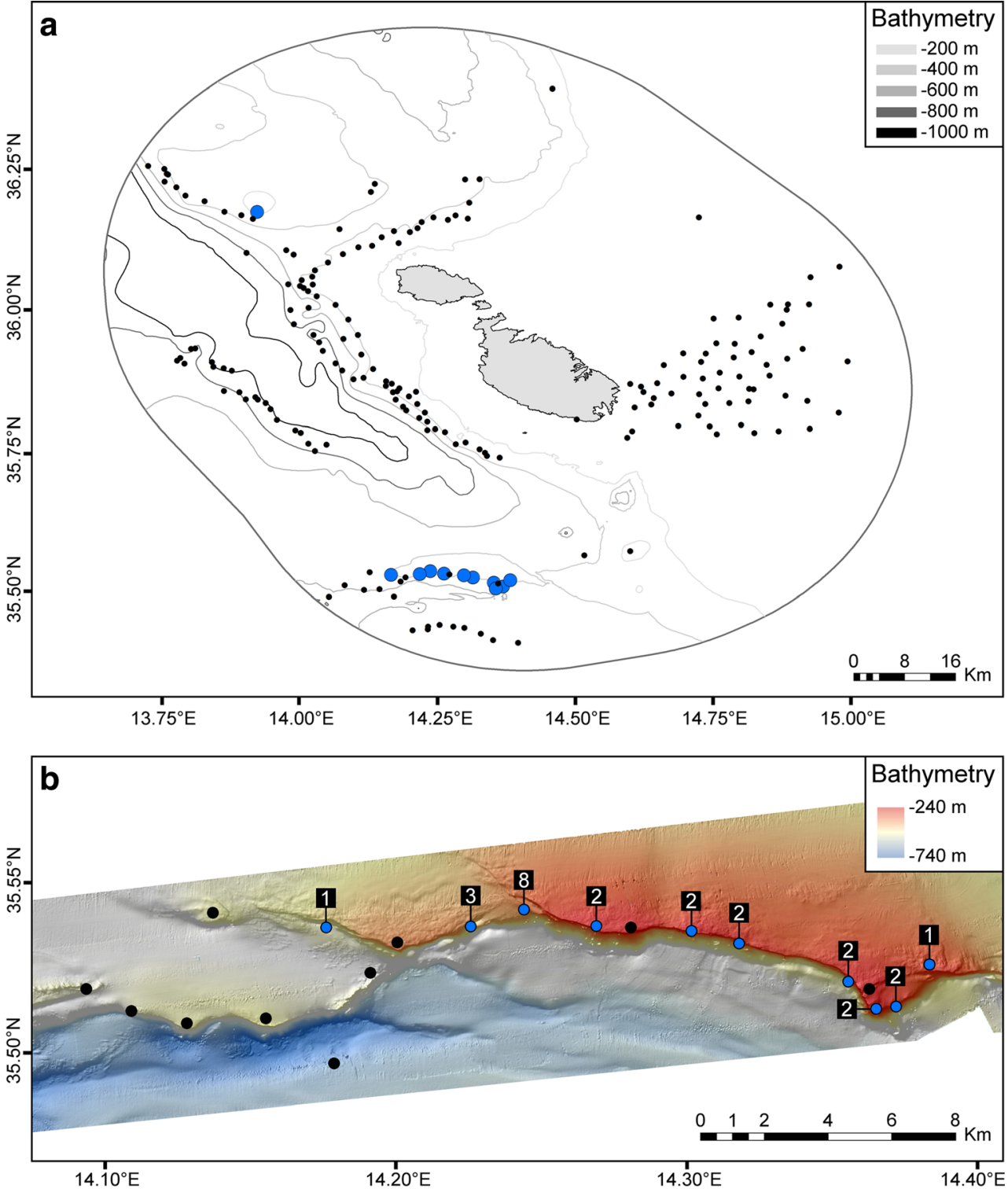

to be no information on the duration of the larval phase in Coronaster spp., but there is evidence that the larvae of some sea stars can spend months in the water column before settling, especially for deep-sea species where low temperatures allow for low mass-specific respiration rates (Young et al. 1997). A long larval phase would allow larvae to reach coastal regions for uptake with ballast water, survival during transport, and then dispersal to suitable habitats away from the coast after being released in ports.

A long duration of the larval phase would also enable dispersal over long distances, facilitating range expansion. According to Bouchet and Taviani (1992), a larva in the eastern Atlantic may travel up to $115 \mathrm{~km}$ eastwards towards the Strait of Gibraltar in $24 \mathrm{~h}$. The Canary Current, the AlmeríaOran Front and, in the case of deep-water species, the Gibraltar sill itself, present powerful barriers to dispersal of
Atlantic species into the Mediterranean (Patarnello et al. 2007; Danovaro et al. 2010; Vermeij 2012). However, except for strictly bathyal species, the Gibraltar sill is not an impenetrable barrier for some deeper-water macrobenthic species (Bouchet and Taviani 1992; Danovaro et al. 2010), while the effectiveness of the Canary Current and Almería-Oran Front as barriers to dispersal may be weakened by warming or an increased frequency of mild winters resulting from global climatic changes (Tintoré et al. 1994; Vermeij 2012). If larvae manage to breach these barriers and enter the western Mediterranean, the powerful Algerian Current would be able to carry them rapidly into the central Mediterranean bypassing most of the western Mediterranean, as may have happened with the sea hare Aplysia dactylomela (Valdés et al. 2013). This could explain the presence of $C$. briareus in the central Mediterranean, despite the absence of records (to date) from 
Table 2 Timeline of descriptions, records, and taxonomic changes for species of the genus Coronaster recorded from the Atlantic

\begin{tabular}{|c|c|}
\hline Author & Contribution \\
\hline Verrill (1882) & Described the species Asterias briareus (type locality: off Chesapeake Bay, USA). \\
\hline Perrier (1884) & $\begin{array}{l}\text { Mentioned the species Coronaster brisingoides (first-ever mention of the genus } \\
\text { Coronaster), but did not include a description of the genus or species. }\end{array}$ \\
\hline Perrier (1885) & $\begin{array}{l}\text { Described the genus Coronaster and its type species Coronaster parfaiti (type locality: } \\
\text { Cape Verde Islands); described C. parfaiti as having a single adambulacral spine and } \\
\text { an orange and white coloration. }\end{array}$ \\
\hline Ives (1888) & $\begin{array}{l}\text { Described the species Coronaster bispinosus as more or less identical to C. parfaiti but } \\
\text { with two adambulacral spines. }\end{array}$ \\
\hline Sladen (1889) & Described the species Asterias volsellata (type locality: off Zebu, Philippine Islands). \\
\hline Perrier (1894) & $\begin{array}{l}\text { Described again the genus Coronaster and } C \text {. parfaiti, based on the same individual in } \\
\text { Perrier (1885), but this time stated that two adambulacral spines are present. } \\
\text { Described the species Coronaster antonii (type locality: off Cape Spartel, Morocco), } \\
\text { noting that it too has two adambulacral spines but differs from } C \text {. parfaiti in terms of } \\
\text { the } R / r \text { ratio, number of arms, and position of wreath of pedicellariae on the spines. }\end{array}$ \\
\hline $\begin{array}{l}\text { Koehler }(1895, \\
1896)\end{array}$ & $\begin{array}{l}\text { Recorded three specimens of } C \text {. antonii from the Bay of Biscay, described as having two } \\
\text { adambulacral spines. }\end{array}$ \\
\hline Verrill (1914) & $\begin{array}{l}\text { Described the genus Heterasterias, differing from Coronaster in having only a single } \\
\text { adambulacral spine; thus transferred A. volsellata to Heterasterias volsellata. } \\
\text { Coronaster antonii was not included under Heterasterias since Perrier (1894) } \\
\text { indicated it has two adambulacral spines. }\end{array}$ \\
\hline Fisher (1917) & $\begin{array}{l}\text { Considered the monacanthid condition of Heterasterias to be insufficient to separate this } \\
\text { genus from Coronaster, given the similarities between } H \text {. volsellata and Coronaster } \\
\text { spp. in other characters; thus transferred } H \text {. volsellata to Coronaster volsellatus. }\end{array}$ \\
\hline $\begin{array}{l}\text { Clark and Downey } \\
\text { (1992) }\end{array}$ & $\begin{array}{l}\text { Examined the type specimens of } C \text {. parfaiti and } C \text {. antonii. Considered } C \text {. parfaiti to be } \\
\text { "an immature specimen of } C \text {. briareus", and } C \text {. antonii as "an immature specimen } \\
\text { not specifically distinct from } C \text {. volsellatus". Hence synonymised } C \text {. parfaiti with } \\
\text { C. briareus, and } C \text {. antonii with } C \text {. volsellatus; the latter species described as having a } \\
\text { bright salmon red colour and only one adambulacral spine. }\end{array}$ \\
\hline
\end{tabular}

the western Mediterranean. Nonetheless, if $C$. briareus has the ability for such long-range dispersal, one might expect it to have colonised eastern Atlantic areas, whereas there are no records close to the Gibraltar Strait since the Coronaster sp. recorded during surveys in Triton Seamount, El Hierro, Gorringe Bank and the Gulf of Cadiz may not be this species.

The third possibility is that $C$. briareus has always been present in Maltese waters but was never recorded. Studies of the Mediterranean deep-sea benthos have traditionally been undertaken using sampling gear such as trawls, dredges and grabs, which preferentially target flat plains with soft substrata. Areas with hard substrata associated with precipitous topographies such as escarpments have not been studied in detail with such sampling gears, and it is only recently with the advent of ROVs that such habitats are being surveyed (Taviani et al. 2016). The Maltese records of $C$. briareus were all from such escarpments or from soft bottoms in their immediate vicinity. Given that only limited ROV surveying was carried out in Maltese waters prior to the project of which the present work forms part, this may have presented the first opportunity to record the species. On the other hand, if $C$. briareus is a native Mediterranean species, it can be expected to occur elsewhere in this sea given its wide distribution range in the Atlantic Ocean. This raises questions as to why it has not been recorded previously in better studied areas such as in the north-western Mediterranean region.

At present, insufficient information is available to indicate which of these three scenarios is the more plausible, so the exact dynamics of occurrence of $C$. briareus in the central Mediterranean remain unknown. As such, increased sampling effort is required elsewhere in the Mediterranean and in the eastern Atlantic in order to ascertain whether this species truly has a disjunct distribution with a gap of some $4000 \mathrm{~km}$ between the Great Meteor and Irving Seamounts and the central Mediterranean, or if there are as yet undiscovered populations in between. Collection of specimens, which is necessary for certain identification of the species, would also provide material for molecular analysis that may shed light on whether the Maltese specimens represent a recent newcomer or a native Mediterranean species. Such analysis may also indicate whether the Mediterranean populations are isolated or well connected with Atlantic ones, especially since the barriers to the influx of echinoderm larvae from the Atlantic may also serve to isolate Atlantic and Mediterranean populations. 
Acknowledgments We thank the crew of the Oceana Ranger for their assistance with the ROV surveys, Jorge Blanco (Oceana, Madrid) for help with plotting the map in Fig. 4, and Marija Sciberras (Bangor University, Wales) for supplying us with some hard-to-find literature. We are grateful to Marco Taviani and Lorenzo Angeletti [nstitute of Marine Sciences National Research Council (ISMAR-CNR), Italy] for providing us with the multibeam data shown in Fig. 4, which was collected during the MEDCOR cruise aboard the R/V Urania as part of the EU HERMES (EC FP6 contract number GOCE-CT-2005-511234-1) and HERMIONE (EC FP7 contract number 226354) programmes. The present work was undertaken as part of the LIFE BaHAR for N2K (LIFE12 NAT/MT/ 000845) Project, which is 50\% cofinanced by the EU LIFE+ Funding Programme and implemented by the Maltese Environment and Resources Authority (ERA), the University of Malta, Fundación Oceana, the Ministry for Sustainable Development, the Environment and Climate Change (MSDEC), and the Department for Fisheries and Aquaculture within MSDEC. We are also grateful to ERA and to the Continental Shelf Department within the Ministry for Transport and Infrastructure (Malta) for granting us the necessary permits to undertake the marine surveys.

\section{References}

Álvarez H, Perry AL, Blanco J, Aguilar R (2016) Expedición 2014 'Atlantic Seamounts' - El Hierro y montañas submarinas. Oceana, Madrid

Angeletti L, Taviani M (2011) Entrapment, preservation and incipient fossilization of benthic predatory molluscs within deep-water coral frames in the Mediterranean Sea. Geobios 44:543-548

Angeletti L, Ceregato A, Ghirelli M, Gualandi B, Lipparini E, Malatesta D, Sperotti A, Taviani M (2010) ROV-SCUBA integrated survey of the Montecristo Island Nature Reserve (Tuscan Archipelago National Park, Mediterranean Sea). Underw Technol 29(3):151-154

Angeletti L, Taviani M, Canese S, Foglini F, Mastrototaro F, Argnani A, Trincardi F, Bakran-Petricioli T, Ceregato A, Chimienti G, Mačić V, Poliseno A (2014) New deep-water cnidarian sites in the southern Adriatic Sea. Mediterr Mar Sci 15:263-273

Bouchet P, Taviani M (1992) The Mediterranean deep-sea fauna: pseudopopulations of Atlantic species? Deep-Sea Res Part A 39: 169-184

Cartes JE, Maynou F, Fanelli E, Romano C, Mamouridis V, Papiol V (2009) The distribution of megabenthic, invertebrate epifauna in the Balearic Basin (western Mediterranean) between 400 and 2300 $\mathrm{m}$ : environmental gradients influencing assemblages composition and biomass trends. J Sea Res 61:244-257

Chao S-M (2000) New records of sea stars (Asteroidea: Echinodermata) from the continental shelf of Taiwan. Zool Stud 39:275-284

Clark AM, Downey ME (1992) Starfishes of the Atlantic. Chapman and Hall, London

Coll M, Piroddi C, Steenbeek J, Kaschner K, Ben Rais Lasram F, Aguzzi J, Ballesteros E, Bianchi CN, Corbera J, Dailianis T, Danovaro R, Estrada M, Froglia C, Galil BS, Gasol JM, Gertwagen R, Gil J, Guilhaumon F, Kesner-Reyes K, Kitsos M-S, Koukouras A, Lampadariou N, Laxamana E, López-Fé de la Cuadra CM, Lotze HK, Martin D, Mouillot D, Oro D, Raicevich S, Rius-Barile J, SaizSalinas JI, San Vicente C, Somot S, Templado J, Turon X, Vafidis D, Villanueva R, Voultsiadou E (2010) The biodiversity of the Mediterranean Sea: estimates, patterns, and threats. PLoS ONE 5(8), e11842. doi:10.1371/journal.pone.0011842

Danovaro R, Company JB, Corinaldesi C, D’Onghia G, Galil B, Gambi C, Gooday AJ, Lampadariou N, Luna GM, Morigi C, Olu K, Polymenakou P, Ramirez-Llodra E, Sabbatini A, Sardà F, Sibuet M, Tselepides A (2010) Deep-sea biodiversity in the
Mediterranean Sea: the known, the unknown, and the unknowable. PLoS ONE 5(8), e11832. doi:10.1371/journal.pone.0011832

Deidun A, Andaloro F, Bavestrello G, Canese S, Consoli P, Micallef A, Romeo T, Bo M (2015) First characterisation of a Leiopathes glaberrima (Cnidaria: Anthozoa: Antipatharia) forest in Maltese exploited fishing grounds. Ital J Zool 82:271-280

Downey ME (1973) Starfishes of the Caribbean and the Gulf of Mexico. Smithsonian Contribution to Zoology No. 126. Smithsonian Institution, Washington

Evans J, Barbara J, Schembri PJ (2015) Updated review of marine alien species and other 'newcomers' recorded from the Maltese Islands (Central Mediterranean). Mediterr Mar Sci 16:225-244

Fabri M-C, Pedel L, Beuck L, Galgani F, Hebbeln D, Freiwald A (2014) Megafauna of vulnerable marine ecosystems in French Mediterranean submarine canyons: spatial distribution and anthropogenic impacts. Deep-Sea Res II 104:184-207

Fisher WK (1917) The Asteroid genus Coronaster. P Biol Soc Was 30: $22-26$

Fisher WK (1919) Starfishes of the Philippine Seas and adjacent waters. United States national museum, bulletin 100 volume 3. Government Printing Office, Washington

Fonseca P, Abrantes F, Aguilar R, Campos A, Cunha M, Ferreira D, Fonseca TP, García S, Henriques V, Machado M, Mechó A, Relvas P, Rodrigues CF, Salgueiro E, Vieira R, Weetman A, Castro M (2014) A deep-water crinoid Leptometra celtica bed off the Portuguese south coast. Mar Biodiv 44:223-228

Freiwald A, Beuck L, Rüggeberg A, Taviani M, Hebbeln D, R/V METEOR Cruise M70-1 Participants (2009) The white coral community in the central Mediterranean Sea revealed by ROV surveys. Oceanography 22:58-74

Galil BS, Marchini A, Occhipinti-Ambrogi A, Minchin D, Narščius A, Ojaveer H, Olenin S (2014) International arrivals: widespread bioinvasions in European Seas. Ethol Ecol Evol 26:152-171

Gebruk AV, Bluhm H, Soltwedel T, Thiel H (2003) A re-description of the enigmatic deep-sea holothurian Irpa abyssicola (Elpidiidae, Elasipodida) with remotely operated vehicle observations on benthic organisms in the Norwegian-Greenland Basin. Sarsia 88:49-54

Hebbeln D, Wienberg C, Beuck L, Freiwald A, Wintersteller P, and cruise participants (2009) Report and preliminary results of RV POSEIDON Cruise POS 385 "Cold-Water Corals of the Alboran Sea (western Mediterranean Sea)", Faro - Toulon, May 29 - June 16, 2009. Berichte aus dem Fachbereich Geowissenschaften der Universität Bremen, No. 273. Bremen University, Bremen

Hiyashi R (1943) Contributions to the classification of the sea-stars of Japan. II. Forcipulata, with note on the relationships between the skeletal structure and respiratory organs of the sea-stars. J Fac Sci Hokkaido Imp Univ, Ser VI Zool 8:133-281

Hudson IR, Wigham BD, Tyler PA (2004) The feeding behaviour of a deep-sea holothurian, Stichopus tremulus (Gunnerus) based on in situ observations and experiments using a Remotely Operated Vehicle. J Exp Mar Biol Ecol 301:75-91

Hughes SJM, Jones DOB, Hauton C, Gates AR, Hawkins LE (2010) An assessment of drilling disturbance on Echinus acutus var. norvegicus based on in-situ observations and experiments using a remotely operated vehicle (ROV). J Exp Mar Biol Ecol 395:37-47

Ives JE (1888) On two new species of starfishes. P Acad Nat Sci Phila 40: $421-424$

Koehler R (1895) Dragages profonds exécutés à bord du "Caudan" dans le golfe de Gascogne (août-septembre 1895). Rapport préliminaire sur les Échinodermes. Rev Biol Nord Fr 7:439-496

Koehler R (1896) Résultats scientifiques de la campagne du "Caudan" dans le golfe de Gascogne, août-septembre 1895. Ann Univ Lyon 26:1-740

Koukouras A, Sinis AI, Bobori D, Kazantzidis S, Kitsos M-S (2007) The echinoderm (Deuterostomia) fauna of the Aegean Sea, and comparison with those of the neighbouring seas. J Biol Res 7:67-92 
Mah C, Hansson H (2016) Coronaster Perrier, 1885. World Register of Marine Species. http://www.marinespecies.org/aphia.php?p= taxdetails\&id=123232. Accessed 10 Aug 2016

McKnight DG (2006) The Marine Fauna of New Zealand: Echinodermata: Asteroidea (Sea-stars). 3. Orders Velatida, Spinulosida, Forcipulatida, Brisingida with addenda to Paxillosida, Valvatida. NIWA (National Institute of Water and Atmospheric Research, Wellington

Mecho A, Billett DSM, Ramírez-Llodra E, Aguzzi J, Tyler PA, Company JB (2014) First records, rediscovery and compilation of deep-sea echinoderms in the middle and lower continental slope of the Mediterranean Sea. Sci Mar 78:281-302

Messing CG, Walker BK, Dodge RE, Reed J, Brooke SD (2006) Calypso LNG Deepwater Port Project, Florida: Marine Benthic Video Survey. http://nsuworks.nova.edu/occ facreports/77. Accessed 10 Aug 2016

Mifsud C, Taviani M, Stöhr S (2009) Remarks on Echinodermata from the South Central Mediterranean Sea based upon collections made during the MARCOS cruise (10 to 20th April, 2007). Mediterr Mar Sci 10(2):63-72

Oceana (2014) The seamounts of the Gorringe bank. http://eu.oceana. org/en/publications/reports/seamounts-gorringe-bank-1. Accessed 10 Aug 2016

Orejas C, Gori A, Lo Iacono C, Puig P, Gili J-M, Dale MRT (2009) Coldwater corals in the Cap de Creus canyon, northwestern Mediterranean: spatial distribution, density and anthropogenic impact. Mar Ecol Prog Ser 397:37-51

Patarnello T, Volckaert FAMJ, Castilho R (2007) Pillars of Hercules: is the Atlantic-Mediterranean transition a phylogeographical break? Mol Ecol 16:4426-4444

Pawson DL, Vance DJ, Messing CG, Solís-Marín FA, Mah CL (2009) Echinodermata of the Gulf of Mexico. In: Felder DL, Camp DK (eds) Gulf of Mexico origin, waters and biota, vol I, Biodiversity. Texas A\&M University Press, College Station, pp 1177-1204

Perrier E (1884) Mémoire sur les étoiles de mer recueilliés dans la mer des Antilles et le golfe du Mexique durant les expéditions de dragage faites sous la direction de M. Alexandre Agassiz. Nouvelles Arch du Muséum d'Histoire Naturelle 2(6):127-276

Perrier E (1885) Premiére note préliminaire des les Échinodermes, recueillis durant les campagnes de dragages sous-marines du Travailleur et du Talisman. Ann Sci Nat Zool 22(8):1-72

Perrier E (1894) Échinodermes. Expéditions scientifiques du Travailleur et du Talisman pendant les années 1880, 1881, 1882, 1883, 3:1-431

Ramirez-Llodra E, Company JB, Sardà F, Rotllant G (2010) Megabenthic diversity patterns and community structure of the Blanes submarine canyon and adjacent slope in the Northwestern Mediterranean: a human overprint? Mar Ecol 31:167-182

Schembri PJ, Dimech M, Camilleri M, Page R (2007) Living deep-water Lophelia and Madrepora corals in Maltese waters (Strait of Sicily, Mediterranean Sea). Cah Biol Mar 48:77-83

Sladen WP (1889) Report on the Asteroidea. Report on the Scientific Results of the Voyage of H.M.S. Challenger during the years 1873-1876. Zoology 30:1-893
Taviani M, Freiwald A, Beuck L, Angeletti L, Remia A, Vertino A, Dimech M, Schembri PJ (2010) The deepest known occurrence of the precious red coral Corallium rubrum (L. 1758) in the Mediterranean Sea. In: Bussoletti E, Cottingham D, Bruckner A, Roberts G, Sandulli R (eds), Proceedings of the International Workshop on Red Coral Science, Management, and Trade: Lessons from the Mediterranean. NOAA Technical Memorandum CRCP-13, Silver Spring, MD, USA, 87-93

Taviani M, Angeletti L, Canese S, Cannas R, Cardone F, Cau A, Cau A, Follesa MC, Marchese F, Montagna P, Tessarolo C (2016) The "Sardinian cold-water coral province" in the context of the Mediterranean coral ecosystems. Deep-Sea Res II. doi:10.1016/j. dsr2.2015.12.008i

Tecchio S, Ramírez-Llodra E, Sardà F, Company JB, Palomera I, Mechó A, Pedrosa-Pàmies R, Sanchez-Vidal A (2011) Drivers of deep Mediterranean megabenthos communities along longitudinal and bathymetric gradients. Mar Ecol Prog Ser 439:181-192

Terribile K, Evans J, Knittweis L, Schembri PJ (2016) Maximising MEDITS: using data collected from trawl surveys to characterise the benthic and demersal assemblages of the circalittoral and deeper waters around the Maltese Islands (Central Mediterranean). Reg Stud Mar Sci 3:163-175

Tintoré J, Viúdez A, Gomis D, Alonso S, Werner FE (1994) Mesoscale variability and $Q$ vector vertical motion in the Alboran Sea. In: La Viollette PE (ed), Seasonal and Interannual Variability of the Western Mediterranean Sea. Coastal Estuarine Studies, vol. 46. AGU, Washington, pp 47-71

Valdés Á, Alexander J, Crocetta F, Yokes MB, Giacobbe S, Poursanidis D, Zenetos A, Cervera JL, Caballer M, Galil BS, Schembri PJ (2013) The origin and dispersal pathway of the spotted sea hare Aplysia dactylomela (Mollusca: Opisthobranchia) in the Mediterranean Sea. Aquat Invasions 8:427-436

Vermeij GJ (2012) The tropical history and future of the Mediterranean biota and the West African enigma. J Biogeogr 39:31-41

Verrill AE (1882) Notice of the remarkable marine fauna occupying the outer banks off the Southern coast of New England, No. 4. Am J Sci (Ser III) 23:216-225

Verrill AE (1884) Notice of the remarkable marine fauna occupying the outer banks off the Southern coast of New England, and of some additions to the fauna of Vineyard Sound. Report Commissioner U S Commission Fish Fisheries 1882(10):641-666

Verrill AE (1914) Monograph of the shallow-water starfishes of the North Pacific coast from the Arctic Ocean to California. Harriman Alaska Series 14:1-408

Vertino A, Savini A, Rosso A, Di Geronimo I, Mastrototaro F, Sanfilippo R, Gay G, Etiope G (2010) Benthic habitat characterization and distribution from two representative sites of the deep-water SML Coral Province (Mediterranean). Deep-Sea Res II 57:380-396

Young CM, Sewell MA, Tyler PA, Metaxas A (1997) Biogeographic and bathymetric ranges of Atlantic deep-sea echinoderms and ascidians: the role of larval dispersal. Biodivers Conserv 6:1507-1522

Ziesenhenne FC (1942) New Eastern Pacific Sea Stars. Alan Hancock Pacific Expeditions 8:197-224 